\title{
Morphological and functional features of ovine follicles in perifusion with pulsatile hormone delivery
}

\author{
M. TERQUI, Françoise BERTHELOT, M.-A. DRIANCOURT
}

Physiologie de la Reproduction, I.N.R.A., Nouzilly, 37380 Monnaie, France.

\begin{abstract}
Summary. Large follicles were obtained from sheep ovaries during the follicular phase, dissected and incubated for $24 \mathrm{~h}$ in a perifusion system. Continuous flow of $\mathrm{B}_{2}$ medium gassed with $\mathrm{O}_{2}$ and $\mathrm{CO}_{2}$ and supplemented with $\mathrm{FSH} / \mathrm{LH}$ pulses every other hour enabled us to measure the steroid secretion rates of each follicle. At the end of the perifusion, the follicles were processed for histological examination. It was demonstrated that $70 \%$ of the follicles were healthy after $24 \mathrm{~h}$ of perifusion. This was associated with a high secretion rate of oestradiol compared to atretic follicles. In contrast testosterone and progesterone secretion rates were similar in healthy and atretic follicles. In both healthy and atretic follicles, repeated gonatrophin pulses produced increases in steroid production. Such a perifusion system might be a valuable tool to study between and within-follicle interactions to get new insights in paracrine and autocrine regulations in the ovary.
\end{abstract}

\section{Introduction.}

Growth of large follicles is regulated by gonadotrophin concentrations, follicular sensitivity to gonadotrophins and intra-ovarian regulations (Bindon and Piper, 1986; Mc Natty and Henderson, 1987; Driancourt and Fry, 1988). However, the way these three factors act to differentiate follicles towards ovulation or atresia and to set up the ovulatory quota in breeds with different levels of ovulation rate is poorly understood. Some insights have been obtained by measuring the ovarian effects of gonadotrophin and growth factor administration on granulosa cell cultures (review: Hsueh et al., 1984). However, the physiological value of the conclusions obtained is limited by (1) the low viability (30-60\%) of the granulosa cells used (Tsonis et al., 1984; Monniaux, 1987), (2) the common use of hypophysectomized DES-treated immature rats as a source of granulosa cells despite the doubts expressed on the physiological value of this model (Sadrkhanloo, Hofeditz and Erickson, 1987), (3) a non-random choice of the granulosa cells used amongst the different subtypes of granulosa cells (Lahteenmaki et al., 1982 ; Erickson et al., 1985), and (4) by the suppression of the interactions between the theca and granulosa layers which play a major role in follicular steroid production (Falck, 1959) and granulosa cell division (Makris et al., 1983). 
Owing to these limitations and to the fact that follicles are the structures encountered in the ovary, an intact follicle perifusion system would be valuable to provide information regarding ovarian sensitivity to gonadotrophins and intraovarian regulations. In this paper, preliminary data on sheep ovarian follicles of different sizes and stages of atresia are presented.

\section{Material and methods.}

Animals and follicle recovery. - 10 Romanov $\times$ Préalpes ewes had their oestrous cycle synchronized by the insertion of FGA-impregnated vaginal sponges (Chronogest, Intervet, Angers, France) for 14 days. At sponge removal $(n=5)$ or $12 \mathrm{~h}$ after sponge removal $(n=5)$ the ewes underwent a first laparotomy during which the three largest follicles of each ovary were labelled with dots of ink in the ovarian stroma surrounding them (Driancourt and Cahill, 1984). $24 \mathrm{~h}$ after this initial laparotomy, the ewes were laparotomized a second time for measurement of the labelled follicles followed by ovariectomy.

Immediately after ovariectomy, the ovaries were stored in culture medium (see below) at room temperature. The follicles which had grown or had kept a steady size between the two laparotomies were than carefully dissected with claws until five to ten layers of theca cells were left. Follicle size was measured under the microscope, and the follicles were transferred to the perifusion system.

Perifusion system. - The perifusion system used is derived from that described by Ménézo, Gérard and Thibault (1976). As shown on figure 1, it is made with a pulse maker, 5 superfusion chambers and a fraction collector.

The pulse maker is built with a Mixograd (Gilson, Villiers-le-Bel, France). The culture medium is stored in two containers, one containing plain medium $(M)$, the other one containing hormone enriched medium $(\mathrm{M}+\mathrm{H})$. Both containers are continously gassed with a $\mathrm{O}_{2}-\mathrm{CO}_{2}$ mixture (95\%-5\%). The origin of the medium delivered to the perifusion system is determined from a graph which is followed by a photoelectric system. When the graph rises, more medium is pumped from the $\mathrm{M}+\mathrm{H}$ container and less from the $\mathrm{M}$ container in order to maintain a steady flow rate $(4 \mathrm{ml} / \mathrm{h})$. Within and between-perifusion coefficients of variation of flow rate were 7 and $12 \%$ respectively.

The perifusion chambers were made of borosilicated glass chromatographic columns (Altex Beckman, Gagny, France). The inner diameter and content of the chambers were $9 \mathrm{~mm}$ and $2 \mathrm{ml}$ respectively. The superfusion chambers were connected to a five-channel fraction collector by Teflon tubling. Owing to this, absorption of steroids was minimized (not detectable for oestradiol, testosterone and progesterone).

Perifusion medium. - The perifusion medium was derived from that described by Ménézo (1976). Its composition is presented on tablel.

All chemicals were of A.R. grade and solvents were used without further purification. Bidistillated water was apyrogen and for culture. Batches of bovine serum albumin (BSA) from Organon (Fresnes, France) were selected for their 


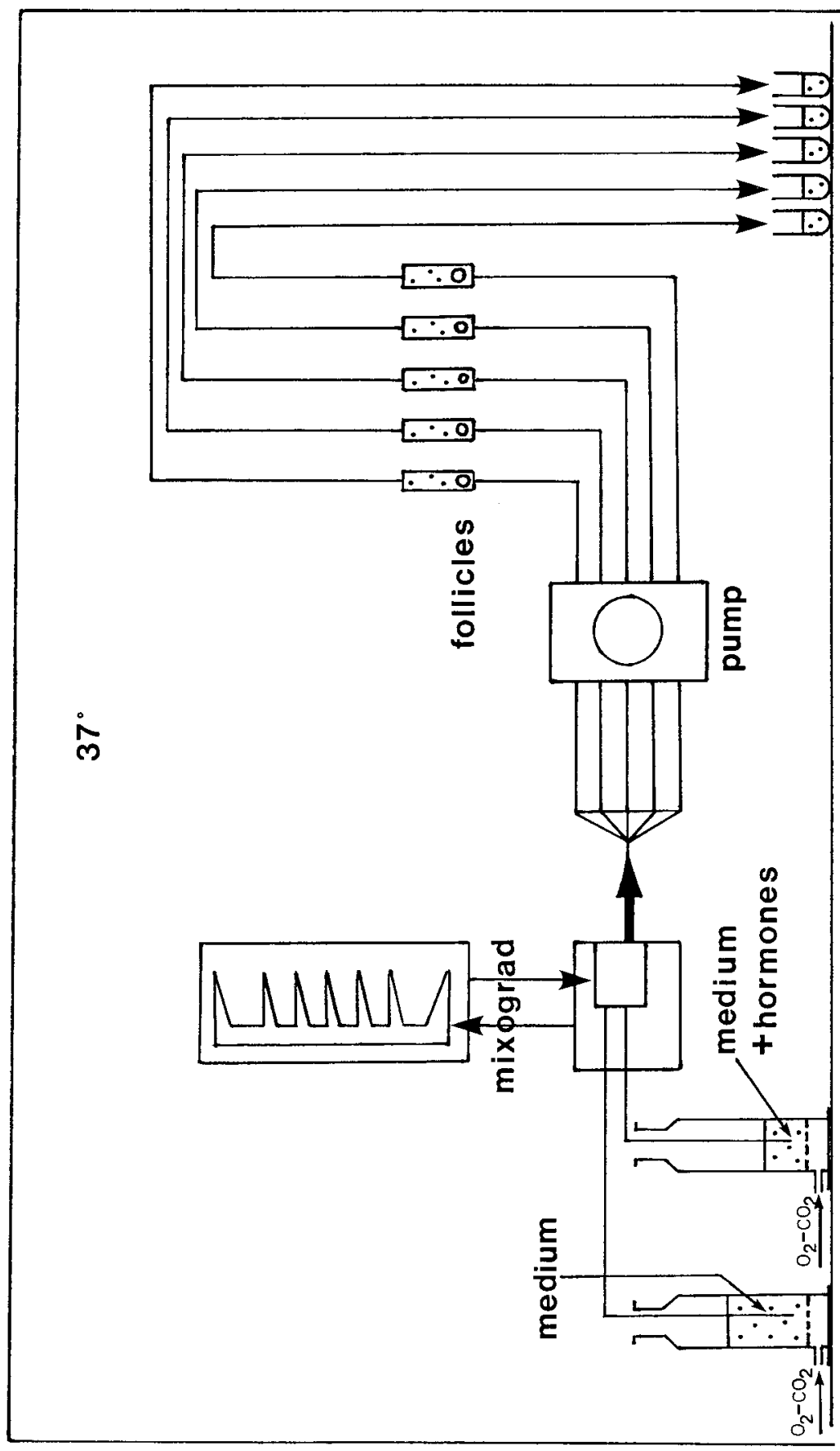

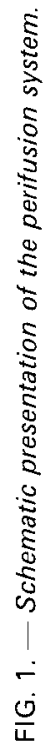


TABLE 1

Composition of the perifusion medium $(\mathrm{mg} / 100 \mathrm{ml})$.

\begin{tabular}{lclc} 
BSA & 1000 & Sodium Chloride & 610 \\
Glucose & 120 & Sodium Bicarbonate & 250 \\
Phenol Red & 2 & Potassium Chloride & 80 \\
Sodium Selenite & 0.026 & Magnesium Sulphate, $7 \mathrm{H}_{2} \mathrm{O}$ & 30 \\
Cholesterol Chs & 6.25 & di-Sodium Phosphate, $12 \mathrm{H}_{2} \mathrm{O}$ & 15.4 \\
Chs Oleate & 3.125 & m-Potassium Phosphate & 6 \\
Chs Arachidonate & 3.125 & Sodium Acetate & 5 \\
Peniciline & $2500 \mathrm{UI}$ & Calcium Lactate & 50 \\
Streptomycine & 4 & Sodium Pyruvate & 25 \\
& & & \\
Taurine & 1.25 & Isoleucine & 2.5 \\
Asparagine & 2.5 & Leucine & 3 \\
Threonine & 2.5 & Tyrosine & 2.5 \\
Serine & 1.5 & Phenylalanine & 2.5 \\
Glutamic Acid & 2.5 & Ornithine & 1.5 \\
Glutamine & 15 & Lysine & 3.5 \\
Glycine & 60 & Tryptophan & 2.5 \\
Alanine & 6.8 & Arginine & 5 \\
Citrullin & 3.5 & Histidine & 2.5 \\
Valine & 7.5 & Proline & 2 \\
Cysteine & 1 & Cystine & 2 \\
Methionine & 1.25 & & \\
& & & 5 \\
Adenine & & Ascorbic Acid & 0.3 \\
Guanine & 0.1 & Folic Acid & 0.1 \\
Cytosine & 0.1 & Calcium Pantothenate & 0.1 \\
Uracil & 0.1 & CyanoCobalamin & 0.1 \\
Thymine & 0.1 & Thiamine & 0.1 \\
& 0.1 & Nicotinic Acid & 0.1 \\
& & Biotin & 0.1 \\
& & Riboflavine & 0.1 \\
\hline & & Pyridoxine &
\end{tabular}

very low content of total oestrogens (conjugated + unconjugated). The epidermal growth factor was purchased from Sigma (La Verpillière, France), ovine FSH (cy.1115) and ovine LH (cy. 1056) had activities equivalent to $1.48 \mathrm{FSH} \mathrm{NIH-S13}$, and to $1.6 \mathrm{LH} \mathrm{NIH-S1} \mathrm{respectively.} \mathrm{Growth} \mathrm{hormone} \mathrm{S-5}$ (1 usp unit/mg) was supplied by the National Institute of Health (Bethesda, Maryland, U.S.A.). Ovine prolactin (Batch $\mathrm{n}^{\circ}$ 01-66 = PRL NIH-S1) and ovine insulin were respectively obtained from Byla (France) and Sigma (La Verpillière, France).

Amino acids, vitamins and salts were first solubilized, then BSA, cholesterol and cholesterol esters were mixed with an aliquote of the above solution and sonicated. Thereafter, this aliquote was mixed with the remainder of the solution. Finally, the medium was sterilized by passing through a $0.22-\mu \mathrm{m}$ pore size filter. The osmotic pressure was between 290 and $300 \mathrm{~m}$ osmoles.

Hormone concentrations in the $\mathrm{M}+\mathrm{H}$ container were $13 \mathrm{ng} / \mathrm{ml}$ for $\mathrm{EGF}$, $20 \mathrm{ng} / \mathrm{ml}$ for $\mathrm{FSH}, 20 \mathrm{ng} / \mathrm{ml}$ for $\mathrm{LH}, 100 \mathrm{ng} / \mathrm{ml}$ for prolactin, $20 \mathrm{ng} / \mathrm{ml}$ for $\mathrm{GH}$ and 
$5 \mu \mathrm{g} / \mathrm{ml}$ for insulin. These concentrations were selected because they were close to those found in follicular fluid (Mc Natty et al., 1981; Hsu, Holmes and Hammond, 1987) or plasma (Davis and Borger, 1974).

Histological techniques and hormone assays. - At the end of the perifusion, each follicle was again measured under the microscope. Therafter, it was fixed in Bouin Hollande fixative, serially sectioned at a $10-\mu \mathrm{m}$ thickness and stained with hematoxylin.

Steroid production in the incubation medium was monitored through the assays previously described (progesterone : Yenikoye et al., 1982 ; testosterone : Garnier, Cotta and Terqui, 1978; oestradiol: Terqui, 1978) using tritiated hormones obtained from Amersham (Les Ulis, France) $\left[\left(1,2,4,6,7^{3} \mathrm{H}\right)\right.$ oestra $1,3,5$ (10) - triene - 3,17 $\beta$-diol (sa 5.2-6.3 TBq/mmol), $\left(1,2^{3 \mathrm{H}}\right.$ ) pregn-4-en-3, 20-dione (sa 3.0-3.9 TBq/mmol), (1,2,6, ${ }^{3} \mathrm{H}$ androst-4-en-3-one-17 $\beta$-ol (sa 3.7 $-4.8 \mathrm{TBq} / \mathrm{mmol})]$. Before assay, the volume of each individual collected fraction was determined with a mean accuracy of $0.025 \mathrm{ml}$. The steroids were measured directly in $0.05 \mathrm{ml}$ of culture medium. The standard curve was also prepared in the culture medium and compared to a control standard curve performed in phosphate buffer $(0.1 \mathrm{M}, \mathrm{NaCl} 9 \mathrm{p} .1000$, gelatin 1 p. 1000 , sodium Azide $1 \mathrm{p} .1000, \mathrm{pH}=7)$ for each steroid assay. Analysis with non-linear curve comparisons of the standard curve in medium and the control standard curve demonstrated that they were parallel since the parameters of the slopes of the logistic function were not different. Computation was done using D6 software and the results were expressed as ng produced per $30 \mathrm{~min}$ and per $24 \mathrm{~h}$.

Data analysis. - Non-linear comparisons were done using CS-NL software (I.N.R.A., Biométrie, Jouy-en-Josas, France) on MULTICS (I.N.R.A., C.T.I.S., Jouy-en-Josas, France). Steroid secretion was computed from D6 software on a MINI-6 computer. This software is based on a five-parameter logistics model described by Huet (1984) and computed using CS-NL transposed routines.

\section{Results.}

Morphological features of the follicles.

A mean of 2.3 ( \pm 1.0$)$ follicles per ewe grew between the two laparotomies at a mean growth rate of $1.0 \pm 0.6 \mathrm{~mm} /$ day. Amongst these 23 follicles, 7 were punctured during dissection. The 16 remaining follicles had a mean size of $5.6 \pm 1.0 \mathrm{~mm}$ before the start of the perifusion. During the $24 \mathrm{~h}$ of perifusion, 9 follicles grew at a rate of $0.3 \pm 0.2 \mathrm{~mm} /$ day, 2 remained at a steady size and 5 shrunk at a rate of $0.3 \pm 0.2 \mathrm{~mm} /$ day. There was no relationship between the growth rates measured in vivo and in vitro.

Histological examination of the follicles at the end of the perifusion demonstrated that 11 follicles were healthy (photos A-B-D), as evidenced by the lack of pycnotic bodies, while 5 follicles were atretic (photo $C$ ). Again, there was no relationship between the atresia ranking (healthy or atretic) and the growth rate in vitro. 

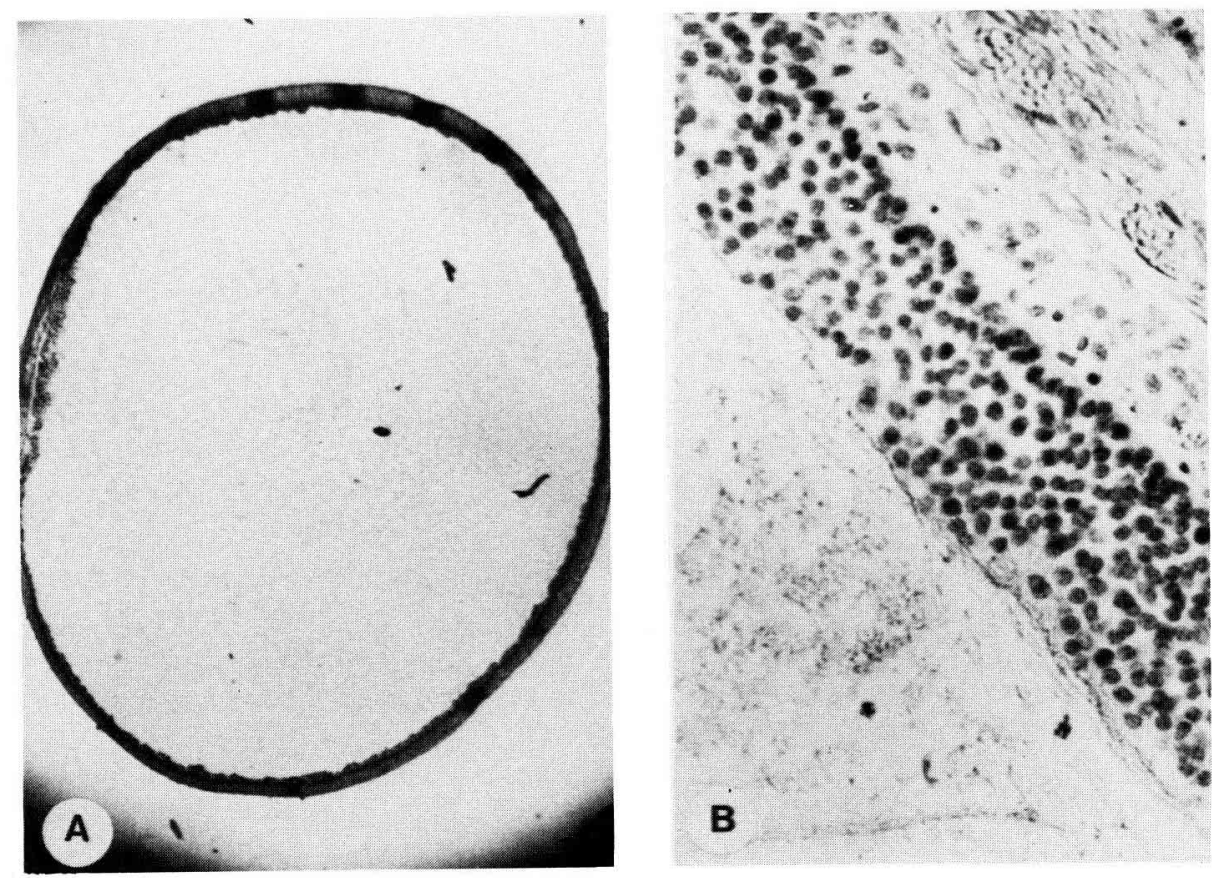

B
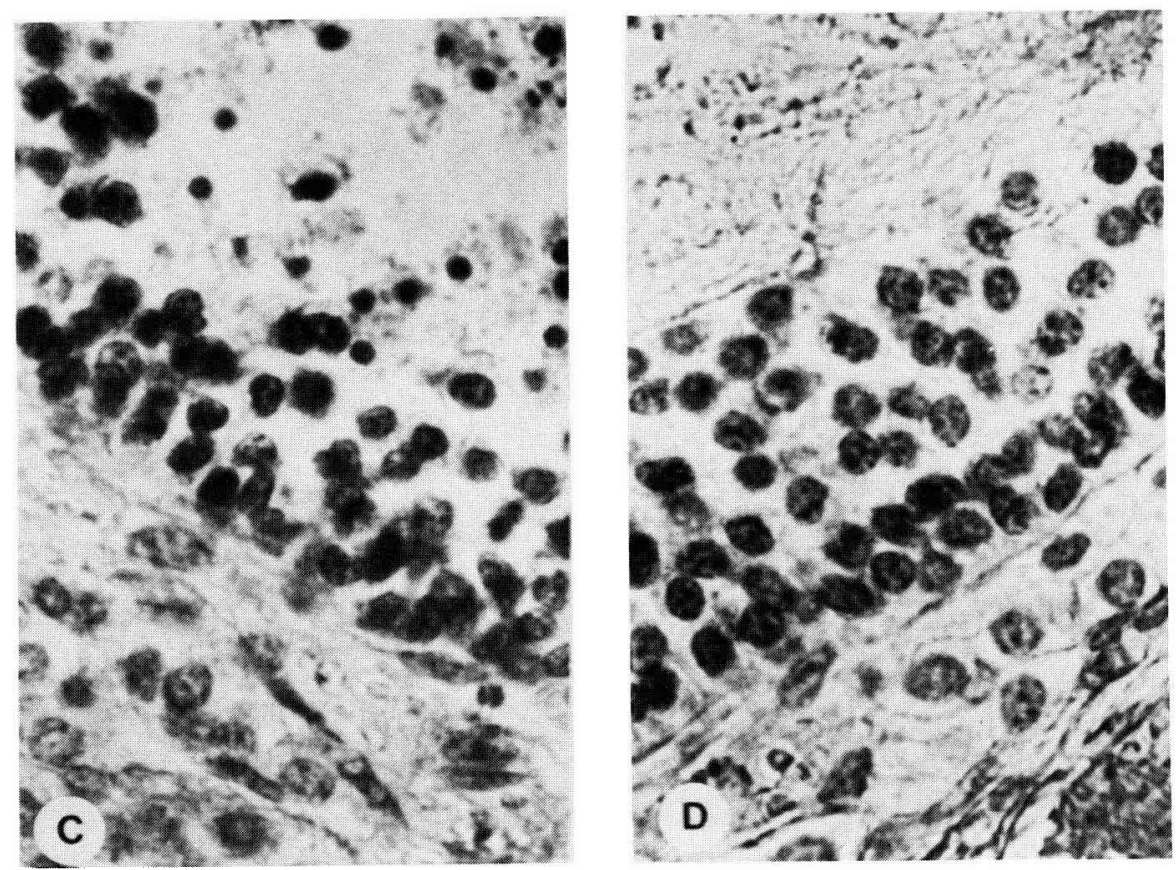

PLANCHE

Histology of follicles

Photo A. - Overall structure of one perifused follicle at the end of perifusion ( $\times 12$ ). Dissection and handling of the follicles sometimes produce local areas of disorganisation (left).

Photo B. - Organisation of the granulose and theca layers in a perifused follicle $(\times 200)$.

Photo C. - Widespread pycnosis amongst the granulosa cel/s in an atretic follicle $(\times 500)$.

Photo D. - Granulosa and theca cells in an healthy looking follicle ( $\times 500)$. 


\section{Functional features of the follicles (figs. 3-5).}

The mean oestradiol production of the 11 healthy follicles during the $24 \mathrm{~h}$ of perifusion was $176 \pm 169 \mathrm{ng} / 24 \mathrm{~h}$ (range 8-516) as opposed to a production of $2 \pm 2 \mathrm{ng} / 24 \mathrm{~h}$ (range $0-7)$ for the 5 atretic follicles $(P<0.01$ Mann \& Whitney $U$ test). The figures for testosterone and progesterone production were $62 \pm 27 \mathrm{ng} / 24 \mathrm{~h}$ and $46 \pm 25 \mathrm{ng} / 24 \mathrm{~h}$ for healthy follicles, while atretic follicles produced $40 \pm 40 \mathrm{ng} / 24 \mathrm{~h}$ of testosterone and $32 \pm 20 \mathrm{ng} / 24 \mathrm{~h}$ of progesterone. As a consequence, the ratio between oestradiol production and production of the other steroids was markedly higher in healthy compared to atretic follicles (healthy $E_{2} / T=3, E_{2} / P=4$, atretic $E_{2} / T=0.05, E_{2} / P=0.06$ ). For healthy follicles, there was a significant correlation between size and oestradiol production ( $r=0.88 P<0.01$ Spearman rank correlation) but no relationships between size and production of progesterone and testosterone could be detected.

Exposure to the hormone pulses (fig. 2) resulted in pulses of increased steroid secretion by healthy as well as atretic follicles (figs. 3, 4, 5), the responses varying markedly with time, with the health status of the follicles and between individual follicles. In follicles where a pulsatile pattern of steroid production was apparent, hormone pulses induced a 2 -fold increase in oestradiol production, a 3 -fold increase in testosterone production and a 4-fold increase in progesterone production.

\section{Discussion.}

Incubation of intact follicles from large domestic animals either in closed or semi-open systems has been widely used to study the steroidogenic features of follicles undergoing final maturation (Baker, Hunter and Neal, 1975 ; Webb and England, 1982; Staigmiller et al., 1982). However, in these systems, the accumulation of follicular metabolites may influence the differentiation and/or secretion of the follicle in an undesired way. In contrast, this technique of perifusion enables the study of dynamic changes in the steroid production of individual follicles in response to the controlled addition of compounds like gonadotrophins without interference of follicular metabolites. The present system, derived from that of Ménézo et al., (1976) demonstrated (1) a good survival of most of the follicles during the $24 \mathrm{~h}$ of perifusion (photos A-D), (2) a high oestradiol production by healthy follicles, (3) a suppressed oestradiol production despite maintained testosterone and progesterone productions in atretic follicles and (4) a sustained sensitivity to gonadatrophins throughout perifusion in healthy and atretic follicles.

That the healthy follicles were very active in terms of oestradiol production is in good agreement with numerous studies (Tsonis et al., 1984 ; Monniaux, 1987 ; Webb, Gauld and Driancourt, 1988). In this study, the secretion rate during the $24 \mathrm{~h}$ was steady and the overall daily production was similar to the follicular fluid oestradiol content (Mc Natty et al., 1981). This steady release throughout time and the good relationship between oestradiol production and gonadotrophin pulses suggest that the amounts of oestradiol measured in the medium are an 


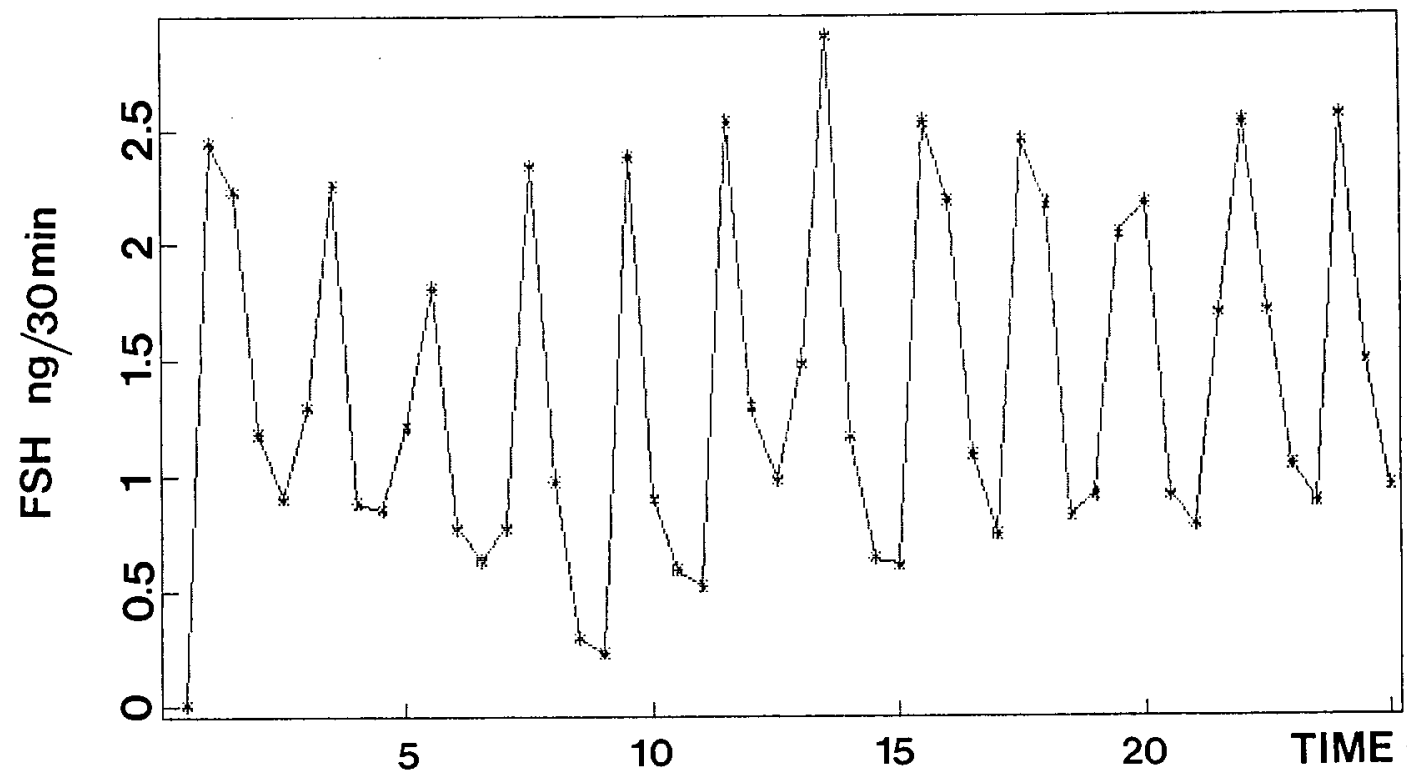

FIG. 2. - Pattern of FSH delivered in the perifusion system ( $\mathrm{ng} / 30 \mathrm{~min}$ ).

actual production and not a plain release of intrafollicular oestradiol. The secretion rate of oestradiol using this perifusion system is, however, markedly lower than the in vivo secretion rate (Mc Natty et al., 1981). Reasons for this discrepancy could be a much slower flow rate in the perifusion system compared to the in vivo conditions (1-3 ml/min: Bruce and Moor, 1976) and/or the inclusion in the perifusion medium of EGF which inhibits $\mathrm{FSH}$-induced oestradiol production (Hsueh et al., 1981 ; Schomberg et al., 1983).

That atretic follicles are unable to produce oestradiol has been repeatedly demonstrated (Carson et al., 1981; Tsonis et al., 1984). This lack of oestradiol production is due to the disappearance of the aromatase enzymes at the early stages of atresia (review: Tsafriri and Braw, 1984). Noteworthy is the observation that atretic follicles retained some sensitivity to gonadotrophins throughout perifusion as demonstrated by pulses of testosterone and/or progesterone associated with the gonadotrophins pulses. This is in good agreement with data from Carson et al. (1979), indicating no reduction in the numbers of gonadotrophin receptors during the early steps of atresia but is in contrast to claims by Henderson et al. (1985), showing a suppressed cAMP response of cells from atretic follicles to a gonadotrophin challenge.

However, this perifusion system still suffers from two limitations: (1) the follicles did not grow in culture at a rate similar to the in vivo rate $(1 \mathrm{~mm} / \mathrm{day}$, Driancourt and Cahill, 1984), (2) at the end of the perifusion, most follicles 


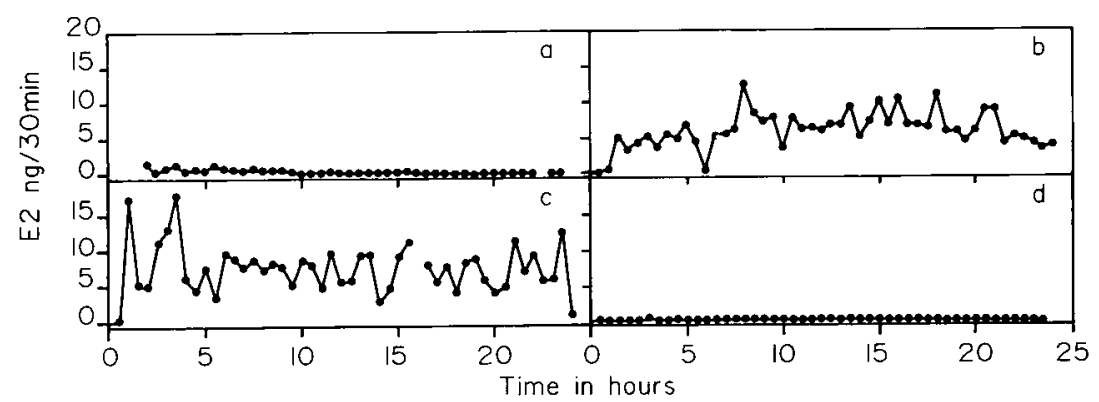

FIG. 3. - Oestradio/ $19 \beta$ production throughout the perifusion period in 4 follicles $(\mathrm{ng} / 30 \mathrm{~min})$ : a, Small $(4,6 \mathrm{~mm}$ in diameter) healthy follicle; $b$, Medium $(5,6 \mathrm{~mm}$ in diameter) healthy follicle) : c, Large $(7.5 \mathrm{~mm}$ in diameter) healthy follicle; $\mathrm{d}$, Small $(4,5 \mathrm{~mm}$ in diameter) atretic follicle.

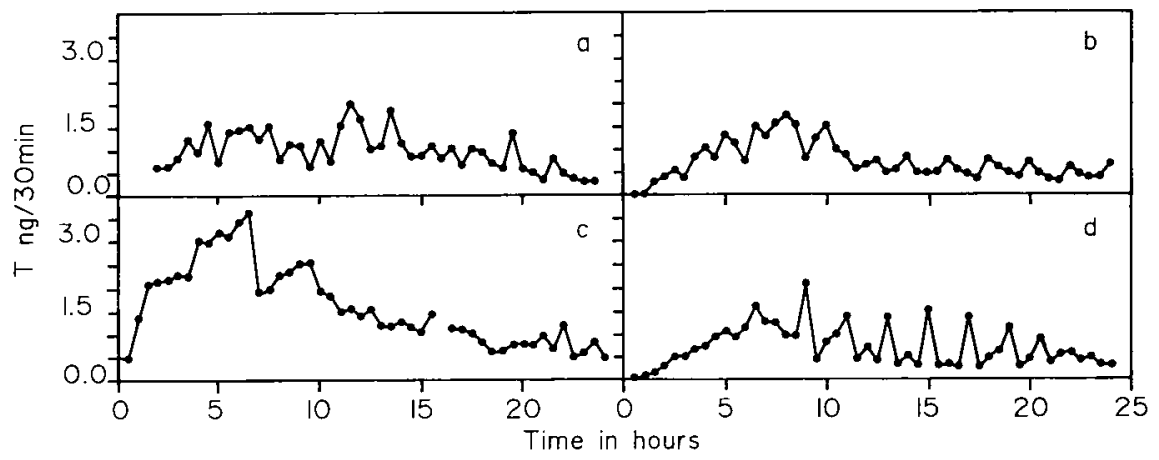

FIG. 4. - Testosterone production throughout the perifusion period of the same follicles (a-d) (ng/30 min).

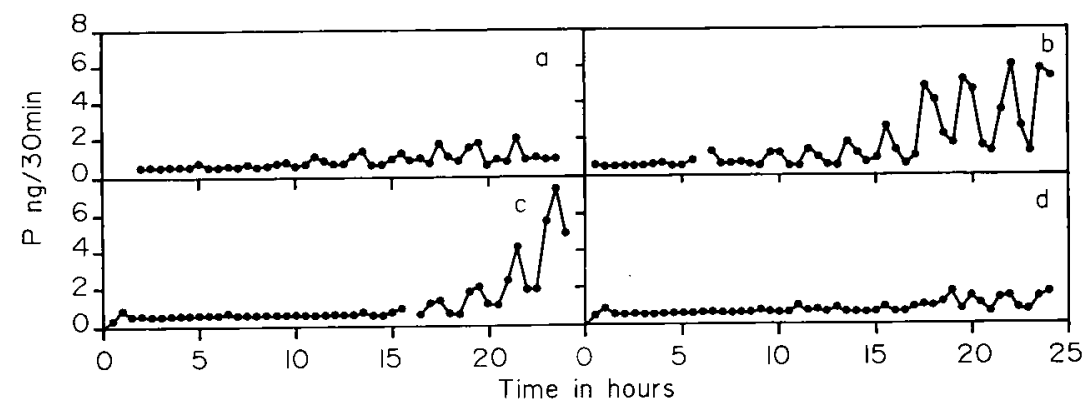

FIG. 5. - Progesterone production throughout the perifusion period of the same follicles (a-d) (ng/30 min). 
presented a rise in progesterone production although there was no evidence of luteinization when they were examined histologically. A change in the LH/FSH ratio of the gonadotrophin preparation used might help to overcome this.

Once this will have been solved, this perfusion system will be valuable (1) to coculture follicles at different stages of differentiation and test direct effects of large follicles on smaller ones (paracine regulation), (2) to check if large follicles contain factors with an autocrine action by comparing oestradiol production before and after follicular fluid aspiration.

Reçu en octobre 1987. Accepté en avril 1988.

Acknowledgements. - This work was funded by the « ATP I.N.R.A. Hormones hypophysaires et fonction de reproduction chez les Vertébrés». We are also grateful to $\mathrm{Dr}$ $\mathrm{Y}$. Combarnous for provision of FSH and LH, Mr D. Tanguy for his valuable help in data management, Mrs M. Durand for histological preparation of the follicles and the staff of the surgery and sheep shed.

Résumé. Caractéristiques morphologiques et fonctionnelles de follicules ovariens périfusés.

Les gros follicules d'ovaires de brebis en phase folliculaire ont été disséqués et incubés pendant $24 \mathrm{~h}$ dans un système de perifusion. Les follicles sont baignés dans du milieu $\mathrm{B}_{2}$ gazé par un mélange $\mathrm{O}_{2}-\mathrm{CO}_{2}$ et supplémenté en FSH et $\mathrm{LH}$ toutes les $2 \mathrm{~h}$. La production des stéroïdes au cours de la périfusion est mesurée puis les follicles sont préparés pour un examen histologique. $70 \%$ des follicles sont sains à la fin de la culture. Ceux-ci secrètent de l'œstradiol en quantité très supérieure aux follicules atrétiques. En revanche, les taux de sécrétion de progesterone et testosterone sont identiques chez les follicules sains ou atrétiques. Durant la durée de la périfusion, les pulses de FSH/LH produisent des augmentations de sécrétion de stéroïdes par les follicules sains et atrétiques. Un tel système de périfusion devrait permettre d'aborder l'étude des régulations paracrines entre follicules et autocrines à l'intérieur d'un follicule.

\section{References}

BAKER T. G., HUNTER R. H. F., NEAL P., 1975. Studies on the maintenance of porcine graafian follicles in organ culture. Experientia, 31, 133-135.

BINDON B. M., PIPER L. R., 1986. The reproductive biology of prolific sheep breeds. Oxford Rev. Reprod. Biol., 8, 415-451.

BRUCE N. W., MOOR R. M., 1976. Capillary blood flow to ovarian follicles, stroma and corpora lutea of anesthesized sheep. J. Reprod. Fert., 46, 229-304.

CARSON R. S., FINDLAY J. K., BURGER H. G., TROUNSON A. O., 1979. Gonadotropin receptors of the ovine ovarian follicle during growth and atresia. Biol. Reprod., 21, 75-87.

CARSON R. S., FINDLAY J. K., CLARKE I. J., BURGER H. G., 1981. Estradiol, testosterone and androstenedione in ovine follicular fluid during growth and atresia of ovarian follicles. Biol., Reprod., 24, 105-113.

DAVIS S. L., BORGER M. L., 1974. Dynamic changes in plasma prolactin, luteinizing hormone and growth hormone in ovariectomized ewes. J. anim. Sci., 38, 795-802.

DRIANCOURT M. A., CAHILL L. P., 1984. Preovulatory follicular events in sheep. J. Reprod. Fert., 71, 205-211. 
DRIANCOURT M. A., FRY R. C., 1988. Differentiation of the ovulatory follicles in sheep. J. anim. Sci., 66 (suppl. 2), 55-66.

ERICKSON G. F., HOFEDITZ C., UNGER M., ALLEN W. R., DULBECCO R., 1985. A monoclonal antibody to a mammary cell line recognizes two distinct subtypes of ovarian granulosa cells. Endocrinology, 117, 1490-1499.

FALCK B., 1959. Site of production of oestrogen in the rat ovary as studied by microtransplants. Acta. physiol. scand., 47, 1-101.

GARNIER D. H., COTTA Y., TERQUI M., 1978. Androgen radio-immunoassay in the ram : results of direct plasma testosterone and dehydroepiandrosterone measurement and physiological evaluation. Ann. Biol. anim. Bioch. Biophys., 18, $261-281$.

HENDERSON K. M., KIEBOOM L. E., Mc NATTY K. P., LUN S., HEATH D., 1985 . Gonadotrophin stimulated cyclic AMP production by granulosa cells from Booroola $\times$ Romney ewes with and without a fecundity gene. J. Reprod. Fert., 75, 111-120.

HSU C. J., HOLMES S. D., HAMMOND J. M., 1987. Ovarian epidermal growth factor-like activity. Concentrations in porcine follicular fluid during follicular enlargement. Bioch. Biophys. Res. Comm., 147, 242-247.

HSUEH A. J. W., WELSH T. H., JONES P. B., 1981, Inhibition of ovarian and testicular steroidogenesis by epidermal growth factor. Endocrinology, 108, 2002-2004.

HSUEH A. J. W., ADASHI E. Y., JONES P. B. C., WELSH T. H., 1984. Hormonal regulation of the differentiation of cultured ovarian granulosa cells. Endoc. Rev., 5, 76-127.

HUET S., 1984. Dosages radio-immunologiques. Quelles analyses statistiques? Reprod. Nutr. Dévelop., 24, 209-219.

LAHTEENMAKI P., LOBO R., MARRS R., GIBBONS W. E., NAKAMURA K., DI ZEREGA G. S.r 1982. Characterization of porcine granulosa cells by isopycnic gradient centrifugation. Biol. Reprod., 27, 633-640.

MAKRIS A., KLAGSBRUN M. A., YASUMIZU T., RYANR. J., 1983. An endogenous ovarian growth factor which stimulates BALB/3T3 and granulosa cell proliferation. Biol. Reprod., 29, $1135-1141$.

MC NATTY K. P., GIBB M., DOBSON C., THURLEY D. C., FINDLAY J. K., 1981. Changes in the concentration of gonadotropic and steroidal hormones in the antral fluid through the oestrous cycle of the sheep. Aust. J. biol. Sci., 34, 67-80.

Mc NATTY K. P., HENDERSON K. M., 1987. Gonadotrophins, fecundity genes and ovarian follicular function. J. Steroid Bioch., 27, 365-375.

MÉNEZO Y., 1976. Milieu synthétique pour la survie et la maturation des gamètes et pour la culture de l'œu fécondé. C.R. Acad. Sci. Paris, 282, 1967-1970.

MÉNÉZO Y., GÉRARD M., THIBAULT C., 1976. Culture du follicule de de graff de bovin dans un système à courant liquide et gazeux continu. C.R. Acad. Sci. Paris, 283, 1309-1311.

MONNIAUX D., 1987. Short term effects of FSH in vitro on granulosa cells of individual sheep follicles. J. Reprod. Fert., 79, 505-515.

SCHOMBERG D. W., MONDSCHEIN J. S., MAY J. V., 1983. Interactions between hormones and growth factors in the regulation of granulosa cell differentiation in vitro. J. Steroid Bioch., 19, $291-295$.

SADRKHANLOO R., HOFEDITZ C., ERICKSON G. F., 1987. Evidence for widespread atresia in the hypophysectomized estrogen treated rats. Endocrinology, 120, 146-155.

STAIGMILLER R. B., ENGLAND B. G., WEBB R., SHORT R. E., BELOWS R. A., $1982 . \quad$ Estrogen secretion and gonadotropin binding by individual bovine follicles during estrus. J. anim Sci., 55, 1473-1482.

TEROUI M., 1978. Contribution à l'étude des œestrogènes chez la brebis et la truie. Thèse Doct. ès Sci. nat., Paris VI.

TSAFRIRI A., BRAW R., 1984. Experimental approaches to atresia in mammals. Oxford Rev. Reprod. Biol., 6, 226-265.

TSONIS C. G., CARSON R. S., FINDLAY J. K., 1984. Relationships between aromatase activity, follicular fluid oestradiol $17 \beta$ and testosterone concentrations and diameter and atresia of individual ovine follicles. J. Reprod. Fert., 72, 153-163. 
WEBB R., ENGLAND B. G., 1982. Relationship between LH receptor concentrations in thecal and granulosa cells and in vivo and in vitro steroid secretion by ovine follicles during the preovulatory period. J. Reprod. Fert., 66, 169-180.

WEBB R., GAULD I. K., DRIANCOURT M. A., 1988. Growth and atresia of large follicle in three breeds of sheep with differing ovulation rates. (Submitted). )

YENIKOYE A., MARIANA J. C., LEY J. P., JOLIVET E., TEROUI M., LEMON-RESPLANDY M., 1981. Modèle mathématique de l'évolution de la progesterone chez la vache: application et mise en évidence de différences entre races. Reprod. Nutr. Dévelop., 21, 561-576. 